\title{
PETROGENESIS AND GEOCHEMICAL SIGNATURES OF OLIVINE PYROXENITE XENOLITHS FROM IVORY COAST DIAMONDIFEROUS CRETACEOUS KIMBERLITES (WEST- AFRICA CRATON)
}

\author{
Allialy, M.E. ${ }^{1}$, Batumike, J.M. ${ }^{2}$, Djro, S.C. ${ }^{1}$, Coulibaly, Y. ${ }^{1}$, Kouamelan A.N. ${ }^{1}$, Daouda,Y.B. ${ }^{3}$ \\ 1 LGSM UFR-STRM, Université de Cocody-Abidjan,22 B.P. 582 Abidjan 22 Côte d'Ivoire. \\ Corresponding Author: marcephremallialy7@gmail.com \\ 2 Department of Earth and Planetary Sciences, Macquarie University, NSW 2109, Australia \\ 3 Department of geology (Côte d'Ivoire).
}

\section{INTRODUCTION}

The most interest in ultramafic xenoliths related to Ivory Coast diamondiferous kimbrlites is give information on the nature of the lithospheric mantle in West Africa craton.These xenoliths can offer directly important information about upper mantle composition in Man Shield. Knowledge of petrogenesis and geochemical composition is essential to the understanding of many geological phenomena and processes in this area. The present paper is the first general overview of the petrology and geochemistry of representative xenoliths in cretaceous diamondiferous kimberlites from Ivory Coast.

\section{Geological setting}

Seguela diamond-bearing kimberlite field is located in the central-western part of Ivory Coast, $30 \mathrm{~km}$ North of Seguela town. In this region diamonds are found disseminated into eluvia, colluvia and alluvia with an average of $0.3 \mathrm{ct}$ and the source for the diamonds is considered to be the two main kimberlitic dykes of Bobi and Toubabouko. Two companies (Waston \& SODEMI) have been active in mining activities in the places with higher diamond concentration in the filed from Bobi to Toubabouko. In the present days, there is no more industrial activity and only individual diggers are working in the area. The dykes, trending $\mathrm{N} 170^{\circ} \mathrm{E}$, crosscut the granitic plutons and amphibolites of the Palaeoproterozoic Birimian formations of the West-African Craton. The Seguela granite is dated at $2091 \mathrm{Ma}$ (Pouclet et al., 2004, Allialy, 2006, $2008,2011 \mathrm{a} \& \mathrm{~b})$. The dyke of Bobi is $2.5 \mathrm{~km}$ long and 25 to $50 \mathrm{~cm}$ wide. Length of the dyke of Toubabouko reaches $4.5 \mathrm{~km}$ with $80 \mathrm{~cm}$ to $1 \mathrm{~m}$ thickness. In the northern part of this dyke, a particularly enriched zone was recently discovered forming a 80 -m-diameter large area and $30-\mathrm{m}$ deep pit (N $8^{\circ} 15^{\prime} 22$ ', W $\left.6^{\circ} 37^{\prime} 57^{\prime \prime}\right)$. The age of the Seguela kimberlites is not yet constrained but they are supposed to be Cretaceous, like other occurrences inside West Africa Craton. Most cretaceous kimberlites from Ivory Coast contain mafic and ultramafic xenoliths of upper mantle origin (figs 1, 2).

\section{Analytical Methods}

Minerals compositions of samples were determined with a fully automated CAMECA SX50 electron microprobe at CNRS-Universtéd'Orléans-BRGM joint laboratory. The EMP analytical conditions employed an accelerating potential of $15 \mathrm{kV}, 10-\mathrm{nA}$ beam current, a 5 -Am 


\section{$10^{\text {th }}$ International Kimberlite Conference, Bangalore - 2012}

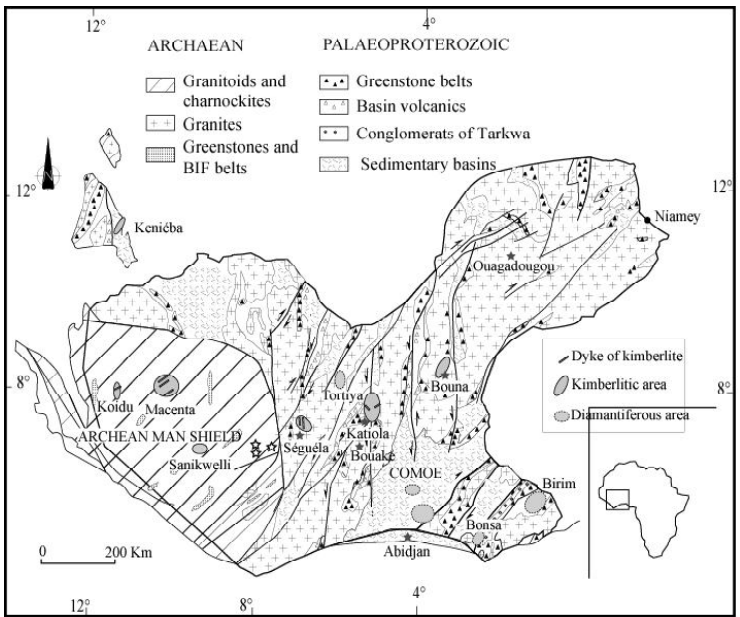

Fig.1. Simplified geological map showing tectono-stratigraphic provinces of archeans and paleoproterozoic formations of the Man Shield (West Africa craton). Modified from Milési et al., (1989) and Olson et al., (1992).

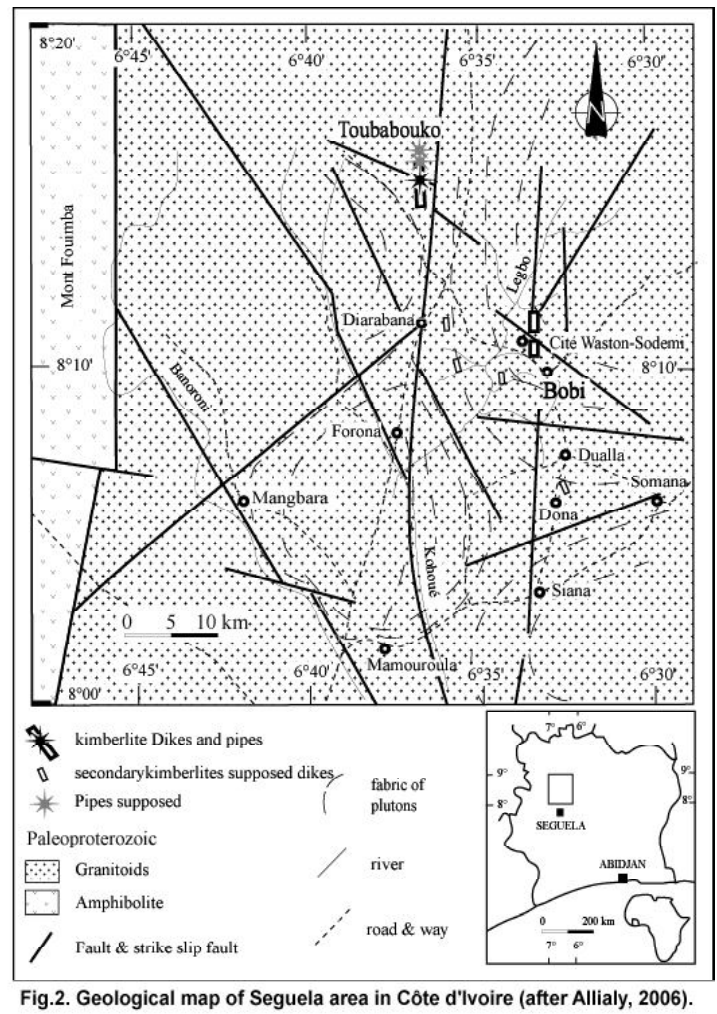

beam size, and 10 s counting time. All analyses underwent a full ZAF correction program. The geochemical data were realized within the analytical laboratory of the CRPG (Nancy,
France). Major oxide analyses were obtained using emission spectroscopy on ICP-AES whereas trace-element geochemistry were determined by mass spectroscopy on ICP-MS. Results for both major and trace elements are given in Table 1, 2, 3, 4. Samples were chipped and cleaned in acid before being crushed and powdered. Powders were mixed by coning several times to ensure homogeneity. $300 \mathrm{mg}$ of the powdered sample were considered for determination of loss on ignition by living the samples in a muffle furnace at $1000^{\circ} \mathrm{C}$ for 12 hours. For preparation of glass fusion discs, sample was mixed with lithium tetraborate $\left(\mathrm{LiBO}_{3}\right)$ and the mixture was heated in a furnace to $1050^{\circ} \mathrm{C}$ and cast in carbon dies to form the discs. Major elements, together with $\mathrm{V}, \mathrm{Cr}, \mathrm{Ni}, \mathrm{Zn}, \mathrm{Ga}, \mathrm{Rb}, \mathrm{Sr}, \mathrm{Y}, \mathrm{Zr}, \mathrm{Nb}, \mathrm{Ba}, \mathrm{La}$, $\mathrm{Ce}, \mathrm{Pb}$, and $\mathrm{Th}$ were analysed on the prepared discs by X-Ray fluorescence (XFR) spectrometer at the Centre de Recherche Pétrographique et Géochimique de Nancy (France) using spectrometer ICP-AES Jobin Yvon JY70 for major element(Si, Al, Fe total, Mn, Mg, Ca, Na, K, P, Ti).

\section{RESULTS}

\section{Petrography}

The xenoliths come from Toubabouko and Bobi dikes and pipes. Two types of xenoliths are observed in Seguela area according to mineralogical and chemical studies. They are mostly spinel lherzolites and olivine pyroxenite. Xenoliths have a fine to medium grained protogranular to porphyroclasts (mainly olivine and orthopyroxene) are highly strained. Phlogopite and amphibole are abundant and may make up to 5 vol.\% (fig 3 ). The amphibole occurs as thick selvages and replacement of pyroxenes. Apatite, green spinel, magnetite, ilmenite and rutile are accessories. Xenoliths characterized by Spinel lherzolite consist of relatively Mg-rich olivine, orthopyroxene, and spinel. Spinels are 


\section{0 $^{\text {th }}$ International Kimberlite Conference, Bangalore - 2012}

higher in $\mathrm{Cr} /(\mathrm{Cr}+\mathrm{Al})$ than those of olivine pyroxene. The forsterite content in olivine ranges from 0.89 to 0.90 and $\mathrm{NiO}=0.35-0.50$ typical for the lherzolite in the world (Frey and Prinz, 1978). In contrast the pyroxenite suite shows a lower forsterite content in olivine varying from 0.8 to 0.82 . $\mathrm{NiO}$ is also lower than in the lherzolites. Orthopyroxenes show only minor difference in composition, and range between En86 and En 90. The orthopyroxene are feroan enstatite according to the pyroxene nomenclature reported by the IMA (1988). The Spinel is Alrich and $\mathrm{Cr}$ - poor in lherzolite and $\mathrm{Cr}$-rich and Al-poor in olivine pyroxenite. Amphibole occurring in mantle xenoliths are pargasite

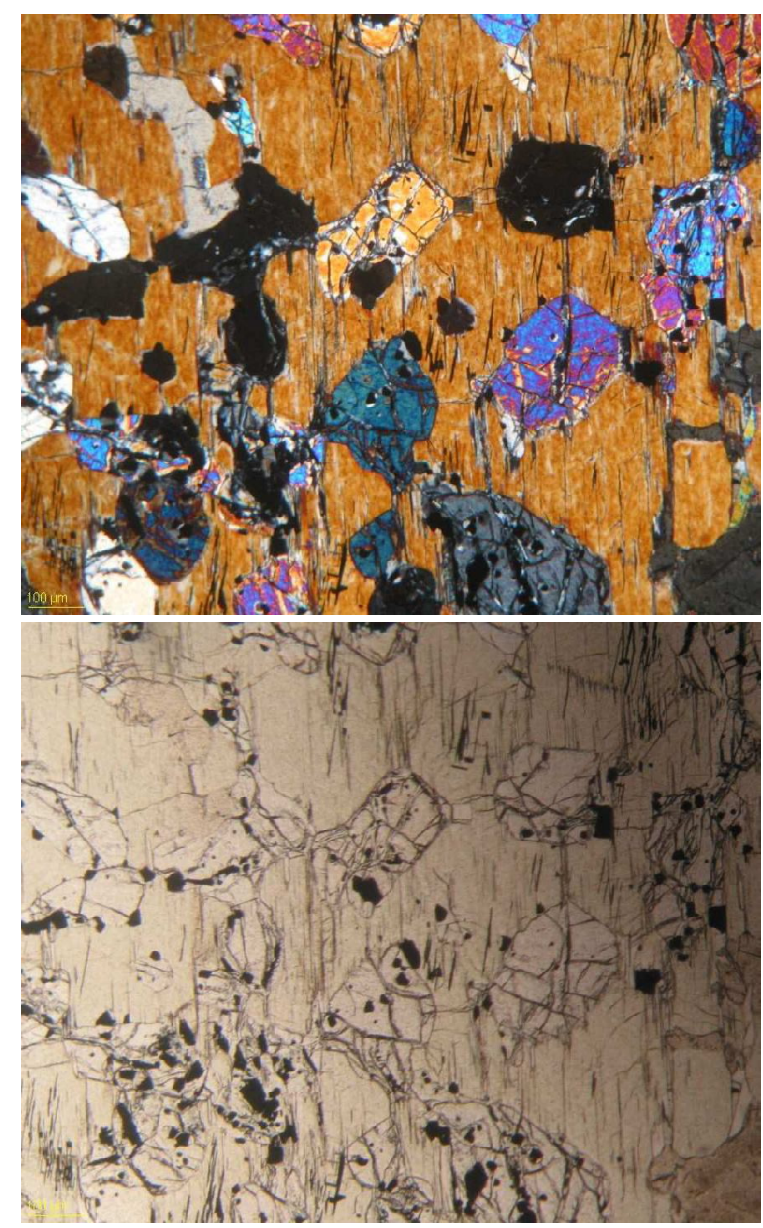

Fig.3. Microscopic observation of Ivory Coast kimberlites xenoliths according to nomenclature of Lake (1978). Phlogopites from the xenoliths have very little variation in composition. They are characterized by high $\mathrm{TiO}_{2}(5-5.5 \mathrm{wt} \%)$ and $\mathrm{Al}_{2} \mathrm{O}_{3}(12-14 \mathrm{wt} \%)$, similar when compared with secondary phlogopites in spinel peridotites (Menzies et al., 1987).

\section{Geochemistry}

The chemical composition of spinel lherzolites show affinity with worldwide peridotites (McDonough, 1990). They are characterized by higher $\mathrm{MgO}, \mathrm{Cr}_{2} \mathrm{O}_{3}$ and $\mathrm{NiO}$ and lower $\mathrm{FeO}, \mathrm{CaO}, \mathrm{Al}_{2} \mathrm{O}_{3}$ and $\mathrm{TiO}_{2}$, and appear to be residues after high degrees of partial melting. The LREE are enriched in the spinel lherzolite xenoliths $(\mathrm{La} / \mathrm{Yb}$ ratio $=8$ and $\mathrm{Sm}=2$ times chondrites). The olivine pyroxenite xenoliths show the lowest LREE enrichments $(\mathrm{La} / \mathrm{Yb}$ ratio $=14$ and $\mathrm{Sm}=2.2$ times chondrites). (Fig.4,5). A number of geothermometers have been proposed that are applicable to the investigated xenoliths (wood, 1974; wells, 1977; Brey and Koehler, 1990). The estimated temperature for the lherzolites and pyroxenite are relatively similar range from $930^{\circ} \mathrm{C}$ to $1115^{\circ} \mathrm{C}$.the mineral assemblage of the lherzolite xenoliths of Ivory Coast indicates a pressure range of 10-15 kbar (35-55 km depth).

\section{DISCUSSION}

The mineralogy and geochemistry of Ivory Coast kimberlites xenoliths present affinity to those found from mantle partial melting axperimental studies. They can, therefore, be interpreted as residues from different degrees of partial melting. The LREE enrichment pattern, however, is incompatible with a partial melting model. This enrichment could be the result of late metasomatic addition components enriched in the incompatible trace elements. Xenoliths show a LREE enrichment which indicates that they have 


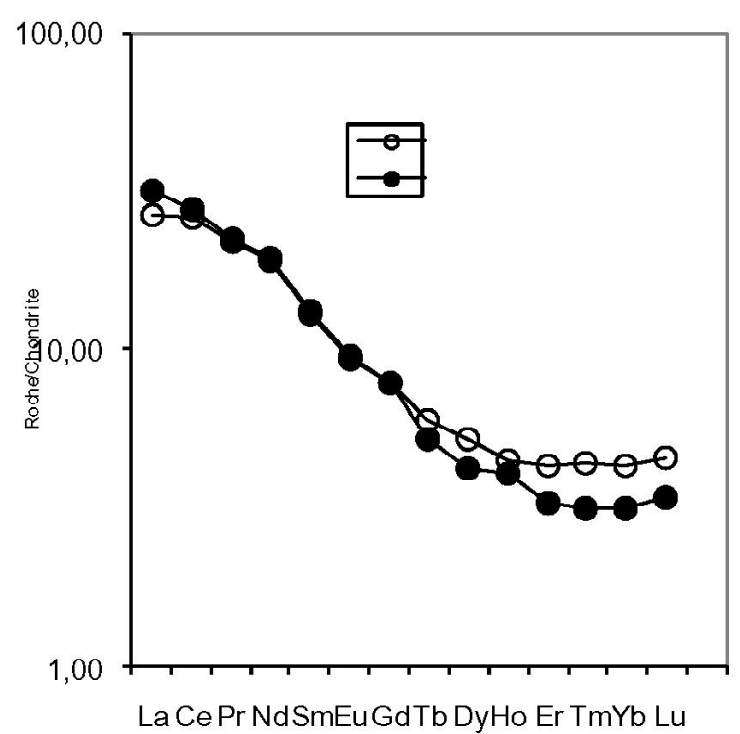

Fig.4. Selected chondrite normalized REE patterns for Ivory Coast kimberlites xenoliths samples (Sun \& McDonough, 1989)

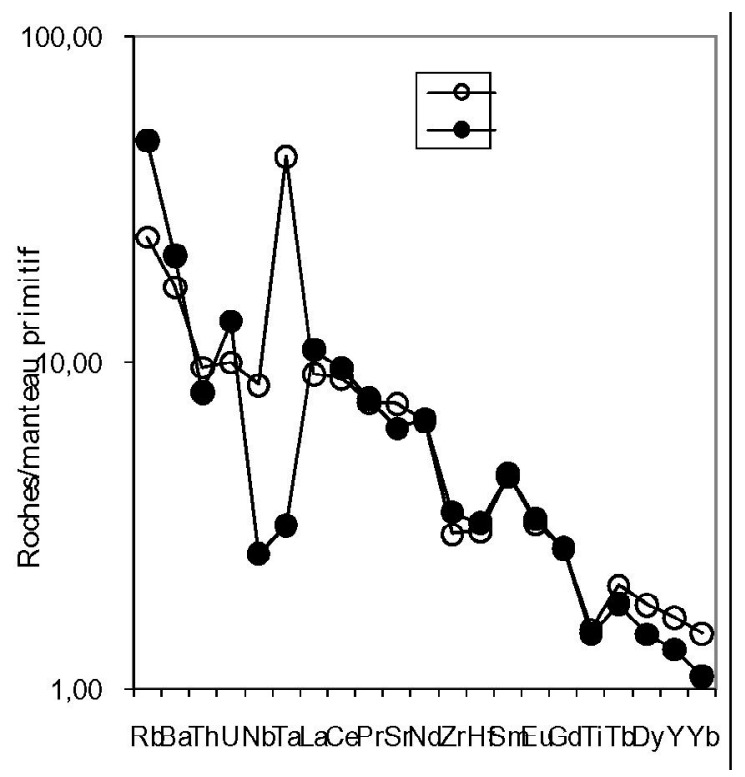

Fig.5. Average from Ivory Coast kimberlites xenoliths elements abundance patterns normalized against primitive mantle (Sun \& McDonough, 1989).

undergone an early partial melting and later enrichment by reactions with fluids after early partial melting and depletion in kimberlitic components. This may indicate that the LREE enrichment of Ivory Coast kimberlites xenoliths is due to metasomatism from atlantic drifting related magmas. All amphibole and phlogopitebearing samples show deformed and equigranular textures. This supports the idea that tectonic deformation may facilitate metasomatism and element mobilization in the upper mantle (Sen and Dun, 1994). The xenoliths from Ivory Coast show equilibrium temperatures between $930^{\circ} \mathrm{C}$ to $1115^{\circ} \mathrm{C}$ indicating that the xenoliths are derived from the lithospheric mantle. The presence of hydrous minerals (amphibole and phlogopite) in the xenoliths suggest percolation of metasomatic $\mathrm{K}$ rich hydrous fluids through the upper most mantle (Menzies and Hawesworth, 1987). $\mathrm{Zr} / \mathrm{hf}$ (39) and $\mathrm{Nb} / \mathrm{Ta}$ (14) ratios from Ivory Coast kimberlites xenoliths are similar to those derived from lithospheric mantle (Mitchell, 1986, 1995). Spinel lherzolites and olivine pyroxenite geochemical signatures present affinity with tholeitic continental basalts. Ivory Coast kimberlites xenoliths tectonic environment is characterized by Continental-Ocean subduction (Allialy, 2006).

\section{CONCLUSION}

The petrogenesis and geochemistry of Ivory Coast kimberlites xenoliths present affinity to those worldwide peridotites, the Syrian xenoliths, Saudi Arabian, Israel and Jordan mantle xenoliths. In addition this studies permit to get new data about lithospheric mantle component in WestAfrican craton.

\section{References}

Allialy, M.E., Djro, S.C., Coulibaly, Y., Kouamelan, A.N., Daouda, Y.B., Pouclet., A. 2008. Comparative geochemistry of Seguela Cretaceous kimberlites, South Africa Group II kimberlites and other worldwide kimberlites. 9 th International Kimberlite Conference, Germany. Extended. Abstracts.

Allialy, M.E., 2006. Pétrologie et géochimie des kimberlites diamantifëres de Séguéla (Centre-Ouest 


\section{0 $^{\text {th }}$ International Kimberlite Conference, Bangalore - 2012}

de la Côte d'Ivoire). Thèse de Doctorat. Univ. Abidjan- Cocody, 162 p.

Allialy, M.E, Djro S.C, Batumike, J.M, Coulibaly Y., Kouamelan Al.N., Daouda Y. (2011a): Chromite,Mg-ilmenite and priderite as indicators minerals of diamandiferous cretaceous kimberlites and lamproites from Côte d'Ivoire (West-Africa). EJSR, ISSN 1450-216X Vol.48 No.4 (2011a) pp.665-693.

Allialy, M.E, Djro S.C, Batumike, J.M, Coulibaly Y., Kouamelan Al.N., Daouda Y. (2011b): Comparative Geochemistry of Seguela Cretaceous Kimberlites, South Africa Group II and Other Worldwide Kimberlites. EJSR, ISSN 1450-216X Vol.48 No.4 (2011) pp.693-718.

Brey G.P., Koehler,T., 1990. Geothrmometry in fourphase lherzolites: II New thermobarometers, and pratical assessment of existing thermometers. Journel of petrology 31, 1353-1378.

Frey, F.A., Prinz, M., 1978. Ultramafic inclusions from San C, Arizona, petrogenesis and geochemical databearing on their petrogenesis. Earth and Planetary Sciences Letters38, 129176.

IMA (Inernation Mineralogy Association) 1988. Nomenclature of pyroxenes. American. Mineralogist 73, 1123-1133.

Lake , B.E., (1978). Nomenclature of amphiboles. Canadian Mineralogist 16, 501-520.
McDnough, W.F., Sun, S.S., 1995. The composition of the Earth. Chem. Geol. 120, 223-253.

Menzies, M.A., Hawesworth, C.J., 1987. Upper mantle process and composition. In Nixon, P.H. (Ed), Mantle xenoliths. Wiley, Chister pp. 725-738.

Mitchell, R.H., 1995. Kimberlites, orangeites and related rocks. Plenum, New York, 410 pp.

Mitchell, R.H., 1986. Kimberlites Mineralogy, geochemistry, and petrology. Plenum, New York, 442 pp. Pouclet, A., Allialy, M.E., Yao, D.B., Botty, E., 2004. Découverte d'un diatrème de kimberlite diamantifère à Séguéla en Côte-d'Ivoire. C.R. Géosciences., 336, 9-17. Sun, S.S., \& McDonough, W.F., 1989. Chemical and isotopic systematics of oceanic basalts: implications for mantle composition and processes, in: A.D. Saunders, M.J. Norry (Eds.), Magmatism in Ocean Basins, Geol. Soc. London Spec. Pub. N. 42, pp. 313-345.

Sen , C., Dunn, T., 1994. Experimental model metasomatism of spinel lherzolite and the production of amphibolites-bearing peridotite. Contributions Mineralogy Petrology 119, 422-432.

Wells, P.A., 1977. Pyroxene thermometry in simple and complex systems. Contributions Mineralogy Petrology 62, 129-139.

Wood, B.J., Banno, S., 1974. Garnet-orthopyroxeneclinopyroxene relationships in simple and complex systems. Contributions Mineralogy Petrology 42, 109-124. 